\title{
DESKRIPSI KONDISI SANITASI DI PONDOK PESANTREN MODERN ZAM-ZAM MUHAMMADIYAH DESA PERNASIDI KECAMATAN CILONGOK KABUPATEN BANYUMAS TAHUN 2015
}

\author{
Iqmah Setiawati $^{1)}$, Lagiono $^{2)}$ \\ Jurusan Kesehatan Lingkungan, Politeknik Kesehatan Kemenkes Semarang, \\ Jl. Raya Baturaden KM 12 Purwokerto, Indonesia
}

\begin{abstract}
Abstrak
Pondok pesantren merupakan lembaga pendidikan Agama Islam, yang dalam kegiatannya mengembangkan fungsi peningkatan keimanan dan ketakwaan terhadap Allah SWT. Tujuan penelitian untuk mengetahui kondisi sanitasi di lingkungan pondok pesantren. Metode penelitian yang digunakan deskriptif yaitu dengan melakukan pengamatan, pengukuran dan wawancara. Hasil dimasukan dalam bentuk narasi dan tabel, kemudian di analisis dan dihubungkan dengan peraturan yang ada. Hasil penelitian didapatkan bahwa sanitasi pondok pesantren Modern Zam-zam Muhammadiyah termasuk dalam kategori cukup dengan presentase $73 \%$. Kondisi lokasi, lingkungan dan bangunan terawat, dilengkapi pagar, tata ruang dan penggunaannya sesuai dengan fungsinya. Kamar dan ruang masih dalam keadaan kotor tetapi permukaan bagian dalam mudah dibersihkan, dinding berwarna terang, kepadataan hunian 1,23 $m^{2}$ per orang.Jamban dan kamar mandi tidak terpisah, kondisi dinding kamar mandi terdapat kerak. Simpulan penelitian adalah sanitasi pondok pesantren Modern Zam-zam Muhammadiyah termasuk dalam kategori cukup baik.
\end{abstract}

Kata Kunci : Sanitasi, Pondok Pesantren, Kesehatan Lingkungan

\begin{abstract}
[Sanitary Conditions Description Of Zam-Zam Muhammadiyah Modern Boarding school Pernasidi SubDistricts Cilongok District Banyumas Regency Year Of 2015]Boarding school is an Islamic educational institution, which in its activities increasing faith and piety to Allah SWT. The aim of research to determine the sanitary conditions in the boarding school environment. The research method used was descriptive in order making observations, measurements and interviews. The obtained results was reported in narrative form and a table, then analyzed and compared with government regulations. The result showed that the Zam-Zam Muhammadiyah modern boarding sanitation stated in the good enough categories, with total score percentage of $73 \%$. Site conditions, environment and buildings was well-maintained, equipped with fences, layout and used in accordance with its function. Bedroom and the room was still in a dirty state but the inner surface is easy to clean, light-colored walls, occupancy density $1.23 \mathrm{~m}^{2}$ per person. Separate toilet and bathroom, bathroom wall conditions were crusty. The conclusion drawn was Zam-zam Muhammadiyah modern boarding sanitation stated in the good enough categories.
\end{abstract}

Keywords : Boarding School, Sanitation, Environmental Health

\section{PENDAHULUAN}

UU RI No 36 Tahun 2009 tentang kesehatan Pasal 162 upaya kesehatan lingkungan ditujukan untuk mewujudkan kualitas lingkungan yang sehat, baik fisik, kimia, biologi maupun sosial serta memungkinkan setiap orang mencapai derajat kesehatan setinggitingginya. Tujuan pembangunan kesehatan menuju Indonesia sehat 2010 adalah meningkatkan kesadaran, kemauan, dan kemampuan hidup sehat bagi setiap orang agar terwujud derajat kesehatan masyarakat yang optimal melalui terciptanya masyarakat, bangsa, dan Negara Indonesia yang ditandai oleh penduduknya hidup dalam lingkungan dengan perilaku yang sehat, memiliki kemampuan untuk menjangkau pelayanan

1) Email : Iqmahs@gmail.com

2) Email : Lagionoabdulwahid@yahoo.co.id kesehatan yang bermutu secara adil dan merata, serta memiliki derajat kesehatan yang optimal di seluruh wilayah Republik Indonesia (Indonesia Sehat 2010,1999,h.5)

Pondok Pesantren adalah tempat untuk proses belajar mengajar dalam hal agama islam. Dengan demikian Pondok Pesantren juga dapat dikatakan tempat umum karena terdapat sekumpulan orang banyak yang sedang melakukan suatu kegiatan yaitu belajar mengajar agama islam.

Pondok Pesantren yang penulis pilih sebagai objek penelitian adalah Pondok Pesantren Modern Zam-Zam Muhammadiyah yang terletak di Desa Pernasidi Kecamatan Cilongok Kabupaten Banyumas.

Keslingmas Vol. 35 Hal. 1 - 85 Maret 2016 | 60 
Berdasarkan survei yang peneliti lakukan bahwa pondok pesantren tersebut didirikan tahun 2008 oleh KH. Casiwan HS, selain itu pondok pesantren sudah terdaftar di kementerian agama dan pondok pesantren ini sudah dikenal masyarakat luar jawa.

Permasalahan yang muncul setelah saya survei pendahuluan ditemukan tidak tersedia alat pemadam kebakaran, dapur pengap dan pencahayaan kurang serta penempatan barang-barang tidak teratur, kamar tidur untuk santri kurang pencahayaan sehingga dapat menimbulkan kerusakan mata dan kelembaban udara di dalam kamar tidur dapat meningkat akibat kurangnya cahaya sehingga dapat memungkinkan terjadinya ISPA, tempat wudhu putri yang ada di sebelah masjid keadaan lingkungannya kotor dan langit-langit berlubang sehingga memungkinkan terjadinya kecelakaan, air limbah yang dihasilkan dari kegiatan pondok pesantren hanya di salurkan ke saluran irigasi tanpa adanya pengolahan, sampah yang dihasilkan setiap harinya langsung di angkut ke TPA tanpa adanya proses pemilahan, lantai masjid kotor dan di beberapa titik ditemukan kotoran hewan dan alat sholat yang ada di masjid pondok pesantren keadaannya kotor dan berbau.

Data dan informasi Pondok Pesantren Modern Zamzam Muhammadiyah yang beralamat di Desa Pernasidi Kecamatan Cilongok Kabupaten Banyumas, diketahui jumlah santri 397 dengan jenis kelamin keseluruhan laki-laki. Diketahui permasalahan yang sering terjadi adalah penularan penyakit yang berbasis lingkungan misalnya flu dan batuk, scabies, diare. Untuk penyakit flu dan batuk biasanya para santri terkena flu dan batuk dikarenakan pengaruh musim serta makanan yang dibeli oleh santri tersebut. Lalu untuk penyakit scabies pada tahun 2013-2014 terdapat jumlah data hampir 100 orang santri mengidap penyakit scabies dari total santri 397 orang, sedangkan untuk penyakit diare rata-rata perbulan 3-5 orang santri.

Penelitian ini bertujuan untuk mengetahui kondisi sanitasi di Pondok Pesantren Modern Zam-Zam Muhammadiyah Desa Pernasidi Kecamatan Cilongok Kabupaten Banyumas.

\section{BAHAN DAN METODE}

Jenis penelitian ini adalah menggunakan metode deskriptif yaitu menggambarkan keadaan subyek penelitian pada saat sekarang berdasarkan fakta yang ada dan menggunakan checklist dan kuesioner.

Subyek penelitian ini adalah sanitasi di Pondok Pesantren Modern Zam-Zam Muhammadiyah Desa Pernasidi Kecamatan Cilongok Kabupaten Banyumas, dengan variabel yang akan diteliti meliputi kondisi sanitasi lokasi, lingkungan dan bangunan, kondisi sanitasi kamar dan ruang, kondisi sarana sanitasi, kondisi pengelolaan makanan dan minuman, kondisi fasilitas penunjang.
Analisis data yang digunakan adalah analisis dengan menggunakan tabel dan narasi untuk menguraikan data yang di bandingkan dengan ketentuan yang ada.

\section{III.HASIL DAN PEMBAHASAN}

Pondok Pesantren Modern Zam-Zam Muhammadiyah berdiri pada tahun 2008 yang didirikan oleh H. Casiwan HS di sebidang tanah wakaf yang luasnya $440 \mathrm{~m}^{2}$, yang letaknya $15 \mathrm{~km}$ dari perkotaan. Memiliki jumlah pengasuh dan karyawan sebanyak 18 orang dan santri sebanyak 397 dengan jenis kelamin keseluruhan laki-laki.Struktur organisasi pengurus pondok pesantren Modern Zam-zam Muhammadiyah dipimpin oleh Dewan Pembina yang membawahi Pemimpin pondok pesantren (Direktur dan Wakil Direktur/Personalia), Bidang Pengasuhan Santri, Bidang Ibadah, Bidang Bahasa, Bidang Tarbiyah dan Perpustakaan, Bidang Muhadhoroh, Bidang Eskul dan Olahraga, Bidang Tahfidz, Bidang Kesehatan, Bidang Kebersihan dan Lingkungan, Tenaga Pendidik, dan Tenaga Kependidikan. Dengan jumlah keseluruhan sebanyak 70 pengurus pondok pesantren Modern Zamzam Muhammadiyah Desa Pernasidi Kecamatan Cilongok Kabupaten Banyumas. (Profil Pondok Pesantren Modern Zam-Zam Muhammadiyah, 2014, h.5)

Keadaan sanitasi Pondok Pesantren Modern ZamZam Muhammadiyah Desa Pernasidi Kecamatan Cilongok Kabupaten Banyumas dikategorikan cukup dengan presentase (73\%). Ini dilihat dari hasil observasi dan wawancara yang dilakukan oleh peneliti dan untuk lebih jelasnya dapat dilihat pada rincian sebagai berikut :

a. Keadaan Sanitasi Lokasi, Lingkungan dan Bangunan

Hasil pengamatan yang peneliti lakukan pada Pondok Pesantren Modern Zam-Zam Muhammadiyah diperoleh data bahwa lokasi berada pada daerah bebas dari banjir, jauh dari Tempat Pembuangan Akhir (TPA), serta tidak terletak pada daerah rawan kecelakaan dan daerah kebakaran seperti pendaratan penerbangan. Sehingga lokasi tersebut baik digunakan untuk membangun Pondok Pesantren.

Lingkungan sekitar Pondok Pesantren bersih tidak terdapat sampah yang berserakan. Supaya lingkungan komplek pondok terjaga kebersihannya, perlu dilakukan pembersihan halaman setiap hari dan membiasakan membuang sampah pada tempatnya. Namun tempat sampah yang tersedia merupakan tempat sampah yang tidak berpenutup. Sebaiknya tempat sampah tersebut diganti dengan tempat sampah berpenutup hal ini untuk mencegah tempat perkembangbiakan vektor yang dapat menularkan penyakit.

Keslingmas Vol. 35 Hal. 1 - 85 Maret 2016 | 61 
Bangunan Pondok Pesantren Modern Zam-Zam Muhammadiyah dalam keadaan baik, karena masih kuat, utuh, mudah dibersihkan, dan tidak memungkinkan terjadinya kecelakan.

Konstruksi bangunan lantai, dinding, atap, langit-langit, pintu, ventilasi, untuk lebih jelasnya dapat dilihat pada rincian sebagai berikut :

1. Lantai

Keadaan lantai di Pondok Pesantren Modern Zam-Zam Muhammadiyah sudah terbuat dari keramik, bahan kuat, kedap air, permukaan rata, dan tidak licin. Kondisi yang demikian perlu dipertahankan untuk mencegah terjadinya kecelakaan. Menurut Direktorat Jendral PPM dan PL Depkes tahun 2000 lantai memenuhi persyaratan apabila lantai terbuat dari bahan yang kuat, kedap air, permukaan rata, tidak licin dan mudah dibersihkan, bagian lantai yang selalu kontak dengan air harus mempunyai kemiringan yang cukup yaitu antara 2 derajat sampai 3 derajat kearah saluran pembuangan air limbah.

2. Dinding

Dinding Pondok Pesantren Modern ZamZam Muhammadiyah sudah dalam keadaan bersih, kuat dan kedap air, maka dinding di Pondok Pesantren Modern Zam-Zam Muhammadiyah sudah memenuhi persyaratan kesehatan. Supaya dinding tetap dalam kondisi baik perlu dilakukan perawatan secara rutin. Menurut Direktorat Jendral PPM dan PL Depkes tahun 2000 dinding selalu bersih, terbuat dari bahan yang kedap air dan tidak licin serta mudah dibersihkan

3. Atap/Talang

Atap/talang pada Pondok Pesantren Modern Zam-Zam Muhammadiyah sudah baik karena terbuat dari genteng, tidak bocor, keadaan kuat, tidak memungkinkan menjadi sarang serangga dan tikus. Supaya atap/talang tetap dalam kondisi bersih perlu dilakukan pemeriksaan maksimal 2 minggu sekali agar tidak memungkinkan sebagai tempat perkembangbiakan serangga dan tikus, dan tidak ada genangan air. Menurut Direktorat PPM dan PL Depkes tahun 2000 atap/talang selalu bersih, terbuat dari bahan yang kuat, tidak bocor, tidak memungkinkan sebagai tempat perindukan serangga dan tikus, dan tidak rawan kecelakaan.

4. Langit-langit

Langit-langit pada bangunan Pondok Pesantren Modern Zam-Zam Muhammadiyah secara keseluruhankuat, bersih, berwarna terang, mudah dibersihkan, tinggi langit-langit $>2,5$ meter dari lantai, untuk selanjutnya dilakukan perawatan secara rutin. Menurut Direktorat
Jendral PPM dan PL Depkes tahun 2000 langitlangit terbuat dari bahan yang kuat, berwarna terang dan mudah dibersihkan, tinggi langitlangit antara 2,5 meter dari lantai.

5. Pintu

Pintu pada Pondok Pesantren Modern ZamZam Muhammadiyah tidak ada masalah karena sudah sesuai menurut Direktorat jendral PPM dan PL Depkes tahun 2000 yaitu pintu dapat dibuka dan ditutup dengan baik, keadaan kuat, dapat mencegah masuknya serangga, tikus dan binatang penganggu. Untuk kedepannya pintu harus dijaga dan dirawat dengan baik, agar tidak cepat rusak dan tidak memungkinkan untuk masuknya serangga dan tikus serta binatang pengganggu lainnya.

6. Ventilasi atau Penghawaan

Ventilasi atau penghawaan Pondok Pesantren Modern Zam-Zam Muhammadiyah belum memenuhi persyaratan. Sedangkan menurut Direktorat Jendral PPM dan PL Depkes tahun 2000, lubang penghawaan harus dapat menjamin pergantian udara dalam ruang dan kamar dengan luas lubang penghawaan antara 10\%-15\% dari luas lantai. Maka sebaiknya ada penambahan ventilasi bila tidak memungkinkan untuk penambahan ventilasi dapat dilengkapi dengan penghawaan buatan dengan cara mekanis.

b. Keadaan Sanitasi Kamar dan Ruang

Keadaan kamar dan ruang di Pondok Pesantren Modern Zam-Zam Muhammadiyah keadaannya kurang bersih dikarenakan lantai dalam kamar santri kotor dan berdebu, serta penumpukan pakaian kotor di tempat tiduryang diakibatkan dari perilaku santri sendiri, jadi perlu adanya kebersihan kamar sangat menentukan , bila kebersihan terjaga dengan baik maka seluruh penghuni pasti akan merasa nyaman dan tenang karena sanitasi dan hygine terjamin. Maka perlu perawatan secara rutin karena kebersihan tidak terjadi secara spontan.

Kamar yang diperuntukan untuk santri di Pondok Pesantren Modern Zam-Zam Muhammadiyah berjumlah 16 kamar, dengan ukuran setiap kamar 5,1 cm x $6 \mathrm{~cm}=30,6 \mathrm{~m}^{2}$. Sehingga luas seluruh kamar sebesar 30,6 m² x 16 kamar $=489,6 \mathrm{~m}^{2}$. Jumlah seluruh santri penghuni kamar berjumlah 397. Jadi, kepadatan hunian ratarata $1,23 \mathrm{~m}^{2}$ per orang, yaitu jumlah penghuni yang banyak dan tidak sebanding dengan luas lantai, berdasarkan persyaratan Kesehatan Lingkungan Menurut Direktorat Jendral PPM dan PL tahun 2000 tentang kepadatan hunian per jiwa sebesar 4,5 $\mathrm{m}^{2}$ untuk setiap satu orang. Oleh karena itu, belum memenuhi syarat. Hal ini perlu adanya penambahan kamar untuk santri, agar mengurangi kepadatan 
penghuni disetiap kamar, karena dapat mempermudah penularan penyakit.

Penghawaan secara umum disebut juga ventilasi. Fungsi dari penghawaan menurut Direktorat Jendral PPM dan PL tahun 2000 yaitu dapat berfungsi sebagai pergantian udara dalam kamar dan ruang, presentase luas ventilasi atau penghawaan yaitu 10\%-15\% dari luas lantai. Hasil pengukuran luas lantai dan luas ventilasi atau penghawaan yang di butuhkan untuk menghitung presentase ventilasi suatu ruangan yang diperoleh rata-rata $0,80 \%$, dengan demikian penghawaan yang ada belum memenuhi syarat dan tidak menjamin pergantian udara di kamar dan ruang. Maka perlu adanya penambahan ventilasi atau penghawaan di kamar dan ruang, bila tidak memungkinkan untuk pembuatan ventilasi dapat dilengkapi dengan penghawaan mekanis.

Pencahayaan secara umum disebut juga penerangan, dapat berfungsi untuk membaca didalam kamar dan ruang tanpa bantuan penerangan mekanis. Pencahayaan juga dapat dipengaruhi oleh faktor waktu dan cuaca. Hasil pengukuran yang dilakukan mendapatkan rata-rata pencahayaan 95 lux pada pagi hari dan 19,2 lux pada sore hari. Menurut Direktorat Jendral PPM dan PL tahun 2000, standar pencahayaan dalam kamar yaitu 60120 lux. Dari standar tersebut pencahayaan pada pagi hari sudah memenuhi syarat tetapi di sore hari belum memenuhi syarat, maka dari pada itu pada sore hari perlu penambahan pencahayaan buatan, agar lebih terang atau dengan pengecetan dinding dengan warna yang terang.

Kelembaban yang tinggi dapat memicu pertumbuhan jamur serta mikroorganisme lain yang dapat menyebabkan penyakit seperti TBC, flu, alergi, gatal-gatal dan penyakit kulit lainnya. Hasil pengukuran kelembaban yang dilakukan mendapatkan rata-rata sebesar 89,6\%.Menurut Direktorat Jendral PPM dan PL tahun 2000 NAB (Nilai Ambang Batas) suatu kelembaban yaitu 65\%95\%, kamar dan ruang di Pondok Pesantren Modern Zam-Zam Muhammadiyah sudah memenuhi syarat.

Suhu terlalu tinggi dapat menimbulkan dehidrasi pada tubuh manusia, sedangkan suhu yang rendah dapat menyebabkan hipotermia. Hasil pengukuran suhu diperoleh rata-rata suhu ruangan, yaitu $27,3^{\circ} \mathrm{C}$. Menurut Direktorat Jendral PPM dan PL Tahun 2000 standar suhu ruangan yaitu antara $15^{\circ} \mathrm{C}-30^{\circ} \mathrm{C}$ sehingga suhu di ruang dan kamar Pondok Pesantren Modern Zam-Zam Muhammadiyah sudah memenuhi syarat.

c. Keadaan Sarana Sanitasi

1. Penyediaan air bersih

Sumber air bersih yang digunakan di Pondok Pesantren Modern Zam-Zam Muhammadiyah berasal dari sumur bor dan PDAM, selanjutnya pendistribusian air bersih menggunakan sistem perpipaan dan dialirkan ke seluruh kamar mandi yang ada di Pondok Pesantren.

Berdasarkan hasil observasi secara fisik air bersih di Pondok Pesantren memenuhi persyaratan fisik, karena tidak berbau, tidak berasa dan tidak berwarna. Pengukuran debit air bersih mendapatkan hasil sebanyak 72625 liter/hari sehingga masing-masing orang mendapatkan jumlah air bersih sebanyak 175 liter/orang/hari. Sedangkan Menurut Direktorat Jendral PPM dan PL tahun 2000 standar volume air bersih perorang/hari yaitu 100 liter/orang/hari atau cukup untuk memenuhi kebutuhan seluruh penghuni baik pada musim penghujan maupun kemarau. Sehingga volume air yang ada di Pondok Pesantren Modern ZamZam Muhammadiyah telah memenuhi persyaratan yang ada.

2. Jamban dan kamar mandi

Secara fisik jamban dan kamar mandi Pondok Pesantren Modern Zam-Zam Muhammadiyah masih dalam kondisi kotor karena masih terdapat lumut pada dinding kamar mandi, lantai terbuat dari bahan yang kedap air, mudah dibersihkan. Jamban yang ada di Pondok Pesantren Modern Zam-Zam Muhammadiyah berjumlah 70 buah dan kamar mandi berjumlah 70 buah dengan jumlah pemakai 397 orang santri. Berdasarkan peraturan Direktorat Jendral PPM dan PL tahun 2000, yaitu jarak peresapan minimal 10 meter dari sumber air, perbandingan jumlah jamban dan kamar mandi dengan jumlah pemakai adalah 1:15. Jadi jumlah jamban dan kamar mandi di Pondok Pesantren Modern ZamZam Muhammadiyah sudah memenuhi persyaratan yaitu dengan perbandingan jumlah jamban dan kamar mandi dengan jumlah pemakai adalah 1:1:15.

3. Pengelolaan sampah

Pengelolaan sampah di Pondok Pesantren Modern Zam-Zam Muhammadiyah sudah cukup baik, tetapi ada beberapa hal yang belum memenuhi syarat yaitu tempat sampah yang tidak berpenutup. Pengelolaan sampah di pondok ini, petugas kebersihan dari Pondok Pesantren hanya membersihkan halaman, kantor, masjid, dan dapur yang ada di Pondok Pesantren, sedangkan kebersihan dilakukan oleh santri yang sudah terjadwal setiap harinya, mereka membersihkan kamar tidur, kamar mandi, dan kelas yang ada di Pondok Pesantren yang selanjutnya sampah di masukan di dalam karung atau di plastik yang ditempatkan di suatu tempat yang nantinya akan di angkut oleh 
petugas PU (Pekerja Umum) dan di bawa ke TPA setiap 2 kali sehari. Sedangkan menurut Azrul Azwar tahun 1986 dalam hal pembuangan sampah yaitu harus tersedia tempat sampah yang tertutup, terbuat dari bahan yang kuat, kedap air, tahan karat, kemudian jumlah dan volume tempat sampah disesuaikan dengan perkiraan volume tempat sampah yang dihasilkan oleh setiap kegiatan, tersedia tempat pembuangan sampah sementara yang mudah terjangkau kendaraan pengangkut sampah.

4. Saluran pembuangan air limbah

Pembuangan limbah cair dari jamban, kamar mandi dan dari pencucian peralatan dapur dialirkan melalui saluran tertutup dan mengalir menuju septictank. Dengan demikian limbah cair tidak mencemari sumber air bersih yang ada di Pondok Pesantren. Keadaan seperti ini sudah sesuai dengan persyaratan kesehatan lingkungan menurut Direktorat Jendral PPM dan PL tahun 2000, yaitu tidak boleh mencemari sumber air bersih, maka perlu diperhatikan pengelolaan limbah cair atau dengan pembuatan septictank dan peresapannya.

d. Pengelolaan sanitasi makanan dan minuman

Bahan makanan didapat daripasar, bahan makanan diangkut setiap pagi dengankendaraan. Bahan makanan dibeli untuk persediaan selama 1 hari dan disimpan dikulkas. Secara fisik bahan makanan dalam keadaan bersih, utuh dan tidak rusak. Bahan makanan yang telah dibeli disimpan dalam kulkas dan penyimpanan bahan terpisah menurut jenisnya. Pengolahan makanan sudah baik, karena penjamah sudah mencuci tangan sebelum mengolah makanan, tidak merokok, peralatan makanan dalam keadaan baik, tempat pengolahan juga bersih. Pengangkutan makanan menggunakan baskom besar yang terbuat dari plastik. Penyimpanan makanan menggunakan alat masak misalnya wajan selalu tertutup. Penyajian makanan ditempatkan menggunakan piring.

e. Fasilitas penunjang

Hasil survei fasilitas penunjang di Pondok Pesantren Modern Zam-Zam Muhammadiyah tidak tersedia kotak P3K (Pertolongan Pertama Pada Kecelakaan).Kotak P3K (Pertolongan Pertama Pada Kecelakaan) merupakan sebuah kotak yang berisi obat-obatan yang berfungsi untuk memberikan pertolongan pertama pada kecelakaan. Untuk pertolongan pertama bagi santri yang sakit pihak Pondok Pesantren telah bekerjasama dengan dokter.

Alat penunjang kebakaran di Pondok Pesantren Modern Zam-Zam Muhammadiyah juga tidak tersedia. Untuk mencegah apabila terjadi kebakaran penulis memandang perlu disediakan alat tersebut untuk mencegah kerugian bagi keluarga besar Pondok Pesantren.

Alat-alat kebersihan di Pondok Pesantren Modern Zam-Zam Muhammadiyah tidak lengkap, karena pada saat observasi hanya terdapat tempat sampah yang tidak berpenutup, tidak terdapat sapu diruang kelas, tidak ada sikat di kamar mandi. Padahal alat-alat kebersihan tersebut menurut penulis penting untuk dilengkapi. Sehingga jika dilaksanakan kegiatan kerja bakti pondok akan mempermudah santri untuk melaksanakan kegiatan tersebut.

Berdasarkan Pedoman Direktorat PPM dan PL Depkes tahun 2000 tentang pengawasan kualitas lingkungan panti sosial yaitu Pondok Pesantren mempunyai pemadam kebakaran yang mudah dilihat, dijangkau, dan dilengkapi dengan petunjuk pemakainnya. Selain itu tersedia pula sebuah kotak P3K (Pertolongan Pertama Pada kecelakaan) yang berisi obat-obatan. Juga tersedia pengeras suara minimal satu yang letaknya strategis sehingga misal ada pengumuman-pengumuman dari pengurus pondok pesantren santri dapat mendengarnya dengan jelas.

\section{IV.KESIMPULAN}

Berdasarkan hasil survey yang dilakukan pada pondok pesantren Modern Zam-zam Muhammadiyah dapat diambil kesimpulan sebagai berikut :

a. Keadaan sanitasi lokasi, lingkungan dan bangunan termasuk dalam kategori baik dengan prosentase $94 \%$.

b. Keadaan sanitasi kamar dan ruang termasuk dalam kategori cukup dengan prosentase 59\%.

c. Keadaaan sarana sanitasi di Pondok Pesantren Modern Zam-zam Muhammadiyah termasuk kategori baik dengan prosentase $77 \%$.

d. Keadaan sanitasi pengelolaan makanan dan minuman di Pondok Pesantren Modern Zam-zam Muhammadiyah termasuk kategori cukup dengan prosentase $68 \%$.

e. Keadaan fasilitas penunjang di Pondok Pesantren Modern Zam-zam Muhammadiyah termasuk kategori tidak baik dengan prosentase 30\%.

\section{DAFTAR PUSTAKA}

Anwar, dkk. (1998). Pedoman Studi Sanitasi Makanan dan Minuman pada Institusi Pendidikan Tenaga Sanitasi. Jakarta : Depkes RI.

Aris Santjaka. (2014). Diskurs Ilmu Kesehatan Lingkungan. Purwokerto : Politeknik Kesehatan Kementrian Kesehatan Semarang Jurusan Kesehatan Lingkungan Purwokerto. 
Azrul Azwar. (1986). Pengantar Ilmu Kesehatan Lingkungan. Jakarta : Mutiara Sumber Widya.

Departemen Agama RI. (2003). Pola Pembelajaran di Pondok Pesantren. Jakarta : Direktorat Kelembagaan Agama Islam RI.

Departemen Kesehatan RI. (1999). Indonesia Sehat 2010. Jakarta : Departemen Kesehatan RI.

Departemen Kesehatan RI. (2007). Pedoman Penyelenggaraan dan Pembinaan Pos Kesehatan Pesantren. Jakarta : Direktorat Jendral Bina Kesehatan Masyarakat.

Direktorat PPM \&PL Depkes. (2000). Pedoman Pengawasan Kualitas Kesehatan Lingkungan Panti Sosial. Jakarta : Depkes.

Eka Erlis Nurhenifah. (2009). Studi Sanitasi Pondok Pesantren Al-Hikmah II Desa Benda Kecamatan Sirampog Kabupaten Banyumas Tahun 2009, Karya Tulis Ilmiah. Purwokerto : Departemen Kesehatan RI Politeknik Kesehatan Semarang Jurusan Kesehatan Lingkungan Purwokerto.

Hadi Susanto, dkk. (2011). Modul Pelatihan Jabatan Sanitarian Jenjang Ahli. Jakarta : Kemenkes.

Imam Zarkasyi. (2012). Kepemimpinan Kiai dalam Budaya Organisasi. Malang : Aditya Media Publishing.

Profil Pondok Pesantren Modern Zam-Zam Muhammadiyah.

Republik Indonesia. (1998). Manajemen Penelitian. Jakarta : Rineka Cipta.

Suharsini Arikunto. (1998). Manajemen Penelitian. Jakarta : Rineka Cipta.

Suparlan. (2012). Pengantar Pengawasan Hygiene Sanitasi Tempat-tempat Umum dan Usahausaha untuk Umum. Surabaya : Percetakan Duatujuh.

Supri Adiyono. (2013). Studi Deskriptif Sanitasi Pondok Pesantren Miftahul'ulum Desa Wonoyoso Kecamatan Bumirejo Kabupaten Kebumen Tahun 2013. Karya Tulis Ilmiah. Purwokerto : Departemen Kesehatan RI Politeknik Kesehatan Semarang Jurusan Kesehatan Lingkungan Purwokerto.
Tri Cahyono. (2013). Pedoman Penelitian Proposal Penelitian Dan Karya Tulis Ilmiah/Skripsi (Edisi Revisi Ke Tiga. Purwokerto : Kementerian Kesehatan RI Politeknik Kesehatan Depkes Semarang Jurusan Kesehatan Lingkungan.

Yodi Mulyadi, Subdit Penyehatan Permukiman dan Tempat-tempat Umum. Jakarta : Direktorat Penyehatan Lingkungan. 